\title{
Workshop Penulisan Artikel Ilmiah untuk Publikasi Jurnal Nasional Terakreditasi Sinta di IAIN Kediri
}

\author{
Yayan Eryk Setiawan \\ Program Studi Pendidikan Matematika, Fakultas Keguruan dan Ilmu Pendidikan, \\ Universitas Islam Malang \\ Corresponding Author. Email: yayaneryksetiawan@unisma.ac.id
}

\begin{abstract}
This service is in the form of a seminar that aims to provide understanding to students in writing accredited national scientific articles. This service activity was carried out at IAIN Kediri. This seminar activity consists of 4 activities, namely: presentation of material by the servant, review of scientific articles of one of the students by the servant, question and answer, and evaluation of community service. The results of the evaluation of this service activity show that the percentage of the questionnaire filling score is $86.6 \%$ which is in the high category which means that this workshop is very successful in providing understanding to participants in writing scientific articles. This success was due to good cooperation between the committee, presenters, and participants in participating in this workshop. Pengabdi recommends that so that students can write scientific articles, students must understand three knowledge, namely about: writing stages, writing scientific article components and submitting scientific articles to journals.
\end{abstract}

\begin{abstract}
Abstrak: Pengabdian ini berupa kegiatan seminar yang bertujuan untuk memberikan pemahaman kepada mahasiswa dalam menulis artikel ilmiah nasional terakreditasi. Kegiatan pengabdian ini dalksanakan di IAIN Kediri. Kegiatan seminar ini terdiri dari 4 kegiatan, yaitu: presentasi materi oleh pengabdi, reviuw artikel ilmiah salah satu mahasiswa oleh pengabdi, tanya jawab, dan evaluasi pengabdian. Hasil evaluasi kegiatan pengabdian ini menunjukkan bahwa persentase skor pengisian angket adalah 86,6\% yang berada pada kategori tinggi yang memiliki arti bahwa kegiatan workshop ini sangat berhasil dalam memberikan pemahaman kepada peserta dalam menulis artikel ilmiah. Keberhasilan ini dikarenakan terjadi kerja sama yang baik antara panitia, pemateri, dan peserta dalam mengikuti kegiatan workshop ini. Pengabdi merekomendasikan bahwa agar mahasiswa dapat menulis artikel ilmiah, maka mahasiswa harus memahami tiga pengetahuan, yaitu tentang: tahapan menulis, penulisan komponen artikel ilmiah, dan pengiriman artikel ilmiah ke jurnal.
\end{abstract}

\section{Article History:}

Received: 05-09-2021

Reviewed: 22-09-2021

Accepted: 11-10-2021

Published: 13-11-2021

\author{
Key Words: \\ Workshop, \\ Publications, \\ Scientific Articles.
}

\section{Sejarah Artikel: \\ Diterima: 05-09-2021 \\ Direview: 22-09-2021 \\ Disetujui: 11-10-2021 \\ Diterbitkan: 13-11-2021}

\section{Kata Kunci:}

Workshop, Publikasi, Artikel Ilmiah.

How to Cite: Setiawan, Y. (2021). Workshop Penulisan Artikel Ilmiah untuk Publikasi Jurnal Nasional Terakreditasi Sinta di IAIN Kediri. Jurnal Pengabdian UNDIKMA, 2(2), 265-274. doi:https://doi.org/10.33394/jpu.v2i2.4109

\section{Pendahuluan}

Kementerian Pendidikan dan Kebudayaan Derektorat Jenderal Pendidikan Tinggi mewajibkan bahwa untuk lulus dari program sarjana, maka mahasiswa harus menghasilkan artikel atau makalah yang terbit pada jurnal ilmiah. Sedangkan untuk lulus dari program magister, maka mahasiswa harus menghasilkan artikel yang terbit pada jurnal nasional yang diutamakan terakreditasi dikti. Begitu juga untuk lulus dari program doktor, maka mahasiswa juga diwajibkan untuk menghasilkan artikel yang diterima untuk terbit pada jurnal internasional (Surat Edaran Nomor 152/E/T/2012 Perihal Publikasi Karya Ilmiah, 2012). 
Artikel ilmiah ini didefinisikan sebagai publikasi dari ide-ide kita yang disertai dengan bukti-butki empiris. Tujuan dari publikasi artikel ilmiah ini adalah untuk menambah ilmu pengetahuan atau memperbaiki pembelajaran (Creswell, 2012). Selain merupakan syarat kelulusan bagi mahasiswa, publikasi artikel ilmiah juga memiliki beberapa manfaat baik untuk lembaga, dosen, maupun mahasiswa sendiri. Salah satu manfaat publikasi artikel ilmiah bagi lembaga adalah meningkatkan nilai akreditasi lembaga melalui bidang penelitian. Manfaat bagi dosen adalah untuk kenaikan jabatan fungsional dan sebagai rekam jejak untuk meningkatkan kompetensi dosen dalam penulisan artikel ilmiah. Sedangkan manfaat bagi mahasiswa adalah sebagai sarana untuk melatih diri dalam membuat tulisan artikel ilmiah yang benar dan sebagai sarana untuk meningkatkan kualitas tulisan artikel ilmiah. Manfaat lain bagi guru atau dosen adalah mengembangkan inovasi pembelajaran atau untuk kenaikan pangkat bagi guru atau dosen (Setianingsih et al., 2020; Suadiyatno et al., 2020; Utami et al., 2020).

Dengan demikian tidak heran jika beberapa perguruan tinggi mulai merancang kewajiban publikasi artikel ilmiah bagi mahasiswanya, dimana publikasi biasanya dilakukan berada di atas standar yang telah ditetapkan oleh Direktorat Jenderal Pendidikan Tinggi. Misalnya, publikasi untuk mahasiswa Doktor adalah pada jurnal internasional terindeks scopus, publikasi untuk mahasiswa Magister adalah pada jurnal nasional terakreditasi sinta 1 dan 2, dan publikasi mahasiswa Sarjana pada jurnal nasional terekreditasi Sinta 3-6. Oleh karena itu, maka setiap perguruan tinggi hendaknya membekali mahasiswa dengan kemampuan menulis artikel ilmiah yang benar, sehingga dapat menghasilkan artikel ilmiah yang baik dan benar serta dapat lulus tepat waktu dalam menyelesaikan studinya.

Salah satu perguruan tinggi yang membekali mahasiswanya agar dapat menulis artikel ilmiah yang benar adalah Institut Agama Islam Negeri (IAIN) Kediri. Akan tetapi beberapa mahasiswa program studi tadris matematika IAIN Kediri masih memiliki kendala dalam menulis artikel ilmiah. Hasil wawancara dengan 10 mahasiswa program studi tadris matematika menunjukkan beberapa kendala yang dimiliki oleh mahasiswa dalam menulis artikel ilmiah, yaitu: (a) menulis judul artikel, (b) memunculkan masalah penelitian, (c) memilih metode penelitian, (d) memaparkan hasil penelitian, (e) melakukan pembahasan, dan (f) memilih sumber rujukan yang tepat. Masalah-masalah ini penting untuk diselesaikan. Hal ini dikarenakan, artikel ilmiah menjadi persyaratan kelulusan mahasiswa. Dengan demikian, jika mahasiswa terkendala dalam menulis artikel ilmiah, maka mahasiswa akan terkendala kelulusannya. Sebaliknya jika mahasiswa dapat menulis artikel ilmiah dengan baik, maka mahasiswa dapat menyelesaikan pendidikannya dengan baik dan tepat waktu.

Salah satu upaya untuk mengatasi kendala dalam penulisan artikel ilmiah adalah dengan mengadakan kegiatan pengabdian kepada masyarakat yang berupa workshop penulisan artikel ilmiah (Setiawan, 2021b). Berbagai hasil pengabdian menunjukkan bahwa workshop sering digunakan dalam membelajarkan kepada suatu peserta tentang suatu materi tertentu, sehingga peserta lebih memahami apa yang disampaikan oleh pemateri (Hia et al., 2016; Sutrisno \& Zuhri, 2019; Wahyuningtyas \& Ratnawati, 2018). Workshop ini adalah pertemuan untuk membahas mengenai suatu masalah (KBI, 2008). Masalah yang dibahas dalam workshop ini adalah tentang penulisan artikel ilmiah untuk publikasi jurnal nasional tarakreditasi. Dengan demikian kegiatan pengabdian ini berupa kegiatan workshop yang bertujuan agar mahasiswa dapat mengetahui komponen-komponen dari suatu artikel ilmiah. Dengan adanya kegiatan seminar ini, diharapkan mahasiswa mengetahui komponen suatu artikel ilmiah dan kemudian dapat menulis artikel ilmiah dengan benar. Pentingnya workshop ini bagi mahasiswa adalah untuk memahami komponen-komponen yang harus ada dalam 
artikel ilmiah dan memahami langkah-langkah publikasi artikel ilmiah. Dengan demikian mahasiswa dapat melakukan publikasi artikel ilmiah di jurnal nasional terakreditasi yang merupakan syarat kelulusan dari mahasiswa program sarjana, magister, maupun doktor.

\section{Metode Pengabdian}

Kegiatan pengabdian kepada masyarakat ini bertempat di IAIN Kediri. Sasaran dari kegiatan ini adalah mahasiswa program studi tadris matematika. Mitra kegiatan pengabdian ini yang sekaligus sebagai panita pelaksana kegiatan workshop ini yaitu Mahasiswa himpunan program studi tadris matematika IAIN Kediri. Sebelum melaksanakan kegiatan workshop, dilakukan perencanaan dalam waktu 1 bulan untuk menyiapkan materi dan melakukan koordinasi dengan mitra pengabdian. Pada tahap perecanaan ini, pengabdi menyiapkan bahan materi yang berupa PPT dan instrumen evaluasi, sedangkan mitra menyiapkan tempat dan perlengkapan yang dibutuhkan dalam kegiatan ini. Setelah tahap perencanaan ini selesai, maka tahap pelaksanaan. Tahap pelaksanaan dari kegiatan workshop ini terdiri dari empat tahap, yaitu: presentasi, review salah satu artikel ilmiah, tanya jawab, dan evaluasi kegiatan (lihat Gambar 1).

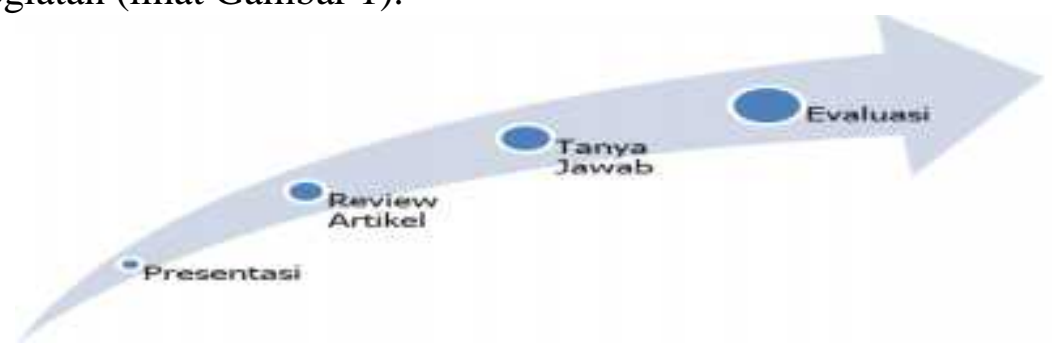

\section{Gambar 1. Tahapan Kegiatan Pengabdian}

Tahap pertama adalah presentasi. Kegiatan yang dilakukan saat presentasi ini adalah pengabdi melakukan presentasi materi tentang penulisan artikel ilmiah. Waktu yang diberikan untuk presentasi adalah sekitar 1 jam.Tahap kedua adalah mereview salah satu artikel ilmiah yang dibuat oleh mahasiswa. Pengabdi diminta untuk mereview mulai dari judul, pendahuluan, metode, hasil penelitian, pembahasan, kesimpulan, ucapan terima kasih, dan daftar rujukan. Tahap ketiga adalah melakukan kegiatan tanya jawab. Dalam kegiatan tanya jawab ini dipandu oleh moderator. Waktu tanya jawab ini sekitar 20 menit.

Tahap terakhir dari kegiatan workshop ini adalah kegiatan evaluasi. Kegiatan evaluasi dilakukan dengan memberikan angket kepada peserta. Terdapat 22 pernyataan yang harus diisi oleh peserta. Setiap pernyataan dalam angket diberikan pilihan: Sangat Tidak Setuju (STS), Tidak Setuju (TS), Netral (N), Setuju (S), dan Sangat Setuju (ST). Masing-masing pilihan tersebut diberi skor 1, 2, 3, 4, 5. Terdapat 27 peserta yang berpartisipasi dalam pengisian angket. Dari 27 peserta tersebut, diperoleh skor minimum adalah $1 \times 22 \times 27=594$ dan skor maksimum adalah $5 \times 22 \times 2 /=2.9 \%$. Dari skor minimum dan maksimum ini ditentukan kategori keberhasilan kegiatan workshop ini dengan menggunakan Tabel 1.

Tabel 1. Kategori Keberhasilan Pengabdian

\begin{tabular}{clll}
\hline No. & Persentase Skor & \multicolumn{1}{c}{ Kategori } & \multicolumn{1}{c}{ Keterangan } \\
\hline 1 & $0-20 \%$ & Sangat Rendah & Sangat Tidak Berhasil \\
2 & $21 \%-40 \%$ & Rendah & Tidak Berhasil \\
3 & $41 \%-60 \%$ & Sedang & Kurang Berhasil \\
4 & $61 \%-80 \%$ & Tinggi & Berhasil \\
5 & $81 \%-100 \%$ & Sangat Tinggi & Sangat Berhasil \\
\hline
\end{tabular}


Teknik analisis data hasil pengisian angket ini dilakukan dengan menentukan persentase dari seluruh skor yang diperoleh oleh peserta workshop. Persentase tersebut selanjutnya digunakan sebagai penentu keberhasilan kegiatan ini yang berdasarkan pada kategori dalam Tabel 1. Keberhasilan kegiatan ini adalah jika hasil pengisian angket menunjukkan pada kategori tinggi atau sangat tinggi. Akan tetapi jika hasil pengisian angket berada di bawah atau sama dengan kategori sedang, maka kegiatan workshop ini tidak berhasil. Peserta juga diminta memberikan pendapatnya mengenai pelaksanaan workshop ini.

\section{Hasil Pengabdian dan Pembahasan}

Sebelum kegiatan workshop dimulai, kegiatan ini dibuka oleh sekretaris program studi tadris matematika IAIN Kediri (lihat Gambar 2). Tujuan dari pembukaan ini adalah agar mahasiswa lebih bersemangat dalam mengikuti kegiatan workshop ini. Selain itu, ketua himpunan mahasiswa program studi (himaprodi) tadris matematika dan ketua panitia juga memberikan sambutan yang menjelaskan tentang tujuan kegiatan workshop, yaitu agar mahasiswa dapat menulis artikel ilmiah dengan benar.

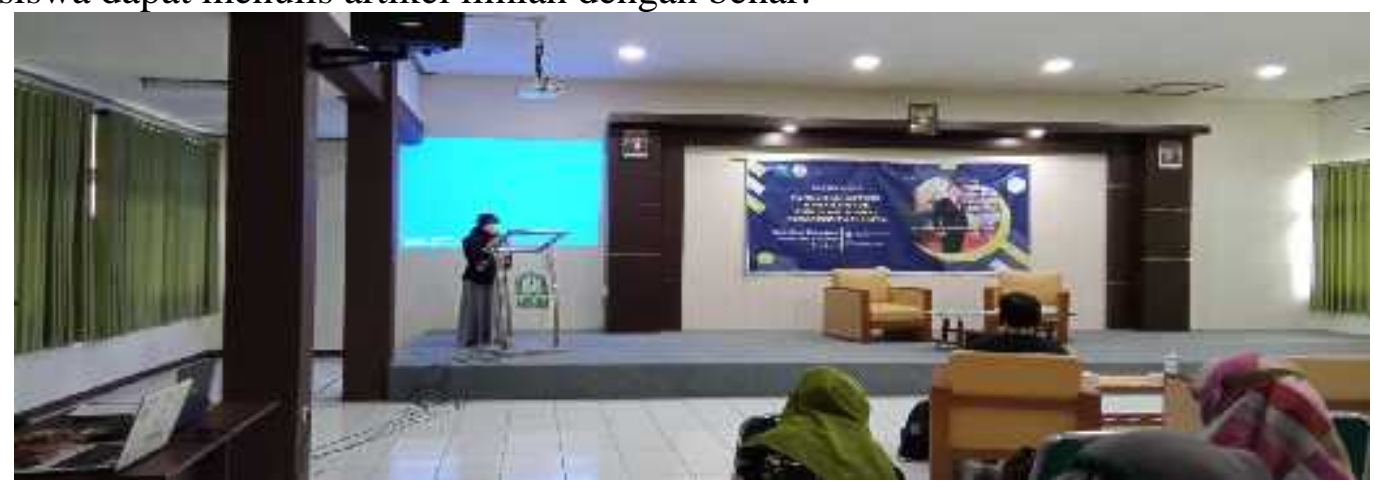

Gambar 2. Sambutan Sekretaris Prodi Tadris Matematika

Setelah kegiatan sambutan selesai, maka kegiatan dilanjutkan langsung pada inti kegiatan workshop. Kegiatan workshop terbagi menjadi 4 kegiatan. Kegiatan pertama adalah pemaparan materi oleh pengabdi tentang penulisan artikel ilmiah terakreditasi sinta. Waktu pemaparan materi ini sekitar 1 jam. Materi yang disampaikan dalam kegiatan ini dapat dilihat dalam Tabel 2.

Tabel 2. Materi Kegiatan Workshop Penulisan Artikel Ilmiah

\begin{tabular}{lll}
\hline No. & \multicolumn{1}{c}{ Topik } & \multicolumn{1}{c}{ Sub Topik } \\
\hline 1 & Pengantar penulisan artikel ilmiah & $\begin{array}{l}\text { Definisi dan pentingnya artikel ilmiah } \\
\text { Mengenal jurnal terakreditasi sinta }\end{array}$ \\
& & Keterampilan yang dibutuhkan untuk \\
& & menulis artikel ilmiah \\
$2 \quad$ Tahapan menulis artikel ilmiah & Memilih jurnal \\
& & Mempelajari contoh artikel ilmiah \\
& Melakukan penulisan artikel ilmiah \\
& Melakukan editor dan penyempurnaan \\
& & artikel ilmiah \\
& Penulisan artikel ilmiah & Komponen artikel ilmiah secara umum \\
& & Komponen Pendahuluan \\
& & Komponen metode \\
& & Komponen hasil penelitian
\end{tabular}


$4 \quad$ Pengiriman artikel ilmiah

Komponen diskusi atau pembahasan

Komponen kesimpulan

Registrasi, pengiriman, pre review, review, revisi, penyelesaian administrasi, dan penerbitan.

Foto kegiatan pemaparan materi ini dapat dilihat dalam Gambar 3. Pemaparan materi ini dimulai dengan memberikan motivasi kepada mahasiswa tentang pentingnya menulis artikel ilmiah, tentang keterampilan yang harus dimiliki oleh seorang penulis, dan karakter yang harus dimiliki oleh seorang penulis. Tujuan pemberian motivasi ini adalah untuk memberikan semangat kepada peserta dalam menulis artikel ilmiah. Setelah motivasi selesai, maka langsung presentasi mengenai penulisan artikel ilmiah.

Presentasi penulisan artikel ilmiah ini pada awalnya menarik perhatian mahasiswa atau peserta. Hal ini dikarenakan presentasi dimulai dengan memberikan motivasi kepada mahasiswa tentang manfaat dan pentingnya menulis. Di tengah-tengah presentasi terkadang membuat mahasiswa menjadi bosan. Hal ini dikarenakan waktu untuk presentasi terlalu lama. Oleh sebab itu, untuk mengatasi hasil ini, maka presentasi yang dilakukan dibagi menjadi empat bagian. Selain itu, agar peserta tidak bosan, maka peran moderator sangat penting dalam mengatur jalannya kegiatan presentasi ini dan pemateri menambahkan dengan bercanda dan bercerita pengalaman dalam menulis. Sehingga mahasiswa menjadi semangat lagi dalam mengikuti kegiatan ini.

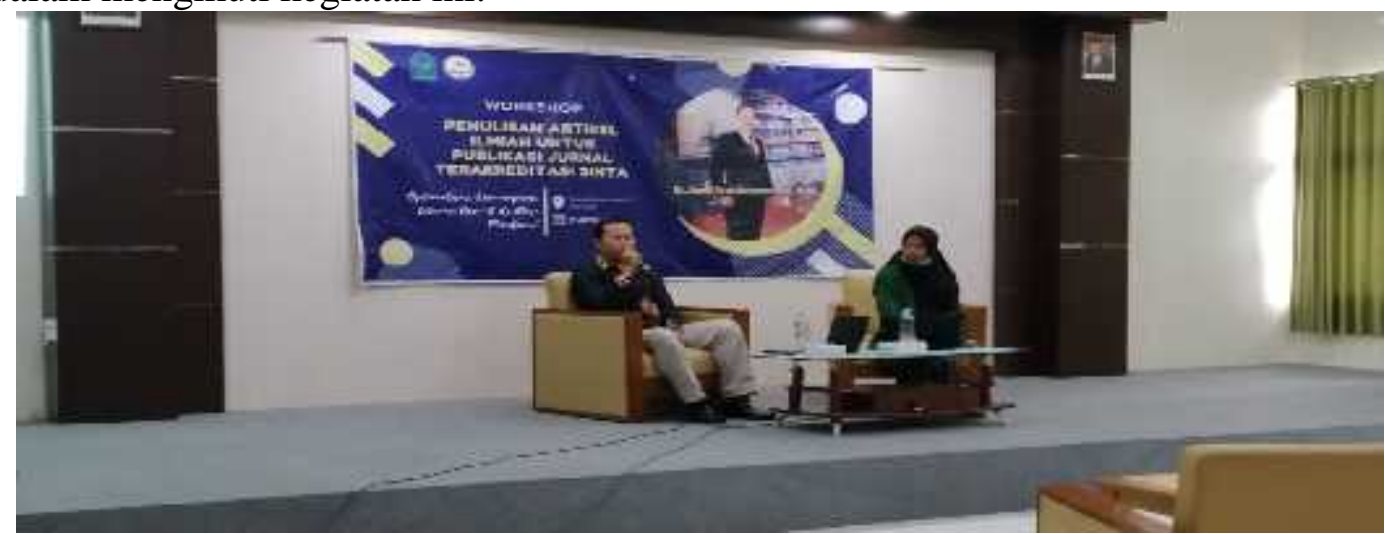

Gambar 3. Presentasi Materi

Setelah kegiatan pemaparan materi selesai, maka kegiatan kedua adalah review artikel ilmiah dari salah satu mahasiswa yang menulis artikel ilmiah. Review dilakukan dengan mengecek kesesuaian komponen artikel ilmiah. Hasil review artikel ilmiah menunjukkan bahwa artikel yang ditulis oleh mahasiswa masih berupa makalah yang tidak dipublikasikan. Hal-hal yang masih belum dilakukan oleh mahasiswa dalam menuliskan artikel yaitu: (a) makalah masih belum sesuai dengan anatomi artikel ilmiah, (b) masalah dan kebaruan penelitian tidak muncul dalam pendahuluan, (c) hasil tidak memuat bukti-bukti temuan, (d) pembahasan tidak menyertakan hasil penelitian sebelumnya (hanya mengaitkan dengan teoriteori yang relevan), dan (e) kesimpulan yang dibuat tidak secara ringkas.

Setelah kegiatan review artikel selesai, maka kegiatan ketiga adalah kegiatan tanya jawab. Kegiatan tanya jawab ini berlangsung sekitar 20 menit. Terdapat beberapa pertanyaan yang diajukan oleh beberapa peserta. Misalnya: (a) apa perbedaan antara keterbatasan penelitian dengen kelemahaman penelitian? (b) bagaimana agar dalam pembahasan tidak terlalu meluas? Jawaban dari pertanyaan pertama yaitu keterbatasan penelitian adalah apa 
yang tidak dilakukan oleh peneliti atau yang akan dilakukan oleh peneliti di penelitian berikutnya. Sedangkan kelemahaman penelitian adalah mengungkapkan kelemahan saat penelitian dilakukan. Dalam penulisan artikel ilmiah, hanya boleh mengungkapkan keterbatasan penelitian, dan kelemahan penelitian tidak boleh diungkapkan. Misalnya, keterbatasan penelitian ini hanya dilakukan pada materi nilai fungsi trigonometri sudut kuadran, sehingga penelitian berikutnya dapat meneliti tentang nilai fungsi trigonometri sudut istimewa. Contoh kelemahan penelitian yaitu kelemahaman penelitian ini adalah menggunakan metode survey, sehingga mungkin terdapat metode lain yang lebih bagus. Kemudian jawaban untuk pertanyaan kedua yaitu agar pembahasan yang dilakukan tidak meluas, maka bahas setiap temuan dalam 1 paragraf dan gunakan hasil penelitian dan teori yang relevan dengan hasil penelitian kita. Dengan demikian, pembahasan tidak akan meluas. Jika hanya sedikit pertanyaan dari peserta, maka moderator dapat memberikan pertanyaanpertanyaan kepada pemateri. Hal ini akan membuat sesi tanya jawab dapat berjalan lancar.

Setelah semua kegiatan selesai, maka kegiatan terakhir dari pengabdian ini adalah evaluasi kegiatan. Evaluasi kegiatan ini bertujuan untuk mengetahui sejauh mana kegiatan workshop ini berhasil dalam memberikan pemahaman terhadap peserta tentang penulisan artikel ilmiah. Evaluasi kegiatan dilakukan dengan pengisian angket. Hasil pengisian angket dapat dilihat dalam Tabel 3.

Tabel 3. Hasil Pengisian Angket

\begin{tabular}{|c|c|c|c|}
\hline No. & Pernyataan & Skor & \%) \\
\hline 1 & Materi terorganisasi dengan baik dan mudah dimengerti & 118 & 94,4 \\
\hline 2 & Materi sangat relevan sesuai yang saya harapkan & 114 & 91,2 \\
\hline 3 & $\begin{array}{l}\text { Materi sudah mencukupi bagi saya untuk mengetahui komponen artikel } \\
\text { ilmiah. }\end{array}$ & 116 & 92,8 \\
\hline 4 & Materi sudah mencukupi bagi saya untuk dapat menulis artikel ilmiah. & 112 & 89,6 \\
\hline 5 & Materi manarik bagi saya untuk mempelajarinya. & 117 & 93,6 \\
\hline 6 & Materi adalah hal yang baru bagi saya. & 111 & 88,8 \\
\hline 7 & $\begin{array}{l}\text { Materi dapat meningkatkan pemahaman saya terhadap cara menulis judul } \\
\text { artikel. }\end{array}$ & 120 & 96 \\
\hline 8 & Materi dapat meningkatkan pemahaman saya terhadap cara menulis abstrak. & 115 & 92 \\
\hline 9 & $\begin{array}{l}\text { Materi dapat meningkatkan pemahaman saya terhadap cara menulis } \\
\text { pendahuluan. }\end{array}$ & 115 & 92 \\
\hline 10 & $\begin{array}{l}\text { Materi dapat meningkatkan pemahaman saya terhadap cara menulis } \\
\text { metode. }\end{array}$ & 114 & 91,2 \\
\hline 11 & $\begin{array}{l}\text { Materi dapat meningkatkan pemahaman saya terhadap cara menulis hasil } \\
\text { penelitian. }\end{array}$ & 116 & 92,8 \\
\hline 12 & $\begin{array}{l}\text { Materi dapat meningkatkan pemahaman saya terhadap cara menulis } \\
\text { pembahasan. }\end{array}$ & 118 & 94,4 \\
\hline 13 & $\begin{array}{l}\text { Materi dapat meningkatkan pemahaman saya terhadap cara menulis } \\
\text { kesimpulan. }\end{array}$ & 119 & 95,2 \\
\hline 14 & Materi workshop sangat bermanfaat dalam menulis artikel ilmiah. & 124 & 99,2 \\
\hline 15 & Pemateri sangat memahami materi yang dipresentasikan. & 119 & 95,2 \\
\hline 16 & Bahasa pemateri lugas dan mudah dimengerti. & 118 & 94,4 \\
\hline 17 & Alokasi waktu penyampaian materi mencukupi. & 115 & 92 \\
\hline
\end{tabular}


Email: pengabdian@undikma.ac.id

\begin{tabular}{|c|c|c|c|}
\hline No. & Pernyataan & Skor & $\%)$ \\
\hline 18 & Pemateri mempresentasikan isi materi dengan baik. & 120 & \\
\hline 19 & Pemateri percaya diri. & 124 & 99,2 \\
\hline 20 & Alokasi waktu untuk tanya jawab mencukupi. & 114 & 91,2 \\
\hline 21 & Pemateri memberikan jawaban secara tepat dan baik. & 116 & 92,8 \\
\hline 22 & Diskusi dan tanya jawab menambah pemahaman saya. & 118 & 94,4 \\
\hline & Total Skor & 2.573 & 86,6 \\
\hline
\end{tabular}

Dari Tabel 3 dapat dilihat bahwa skor total hasil pengisian angket adalah 2.573. Diketahui skor maksimum hasil pengisian angket adalah $5 \times 22 \times 27=2.4 / 0$. Dari skor yang diperoleh dan skor maksimum, maka diperoleh persentase hasil skor pengisian angket, yaitu $\frac{z, 5 / 3}{z, y / 0} \times 100 \%=86,6 \%$. Berdasarkan Tabel 1, maka diperoleh bahwa skor hasil pengisian angket berada pada kategori sangat tinggi. Ini artinya bahwa kegiatan workshop tentang penulisan artikel ilmiah ini berhasil dalam memberikan pemahaman kepada mahasiswa mengenai komponen-komponen dari artikel ilmiah.

Selain menggunakan angket, evaluasi dilakukan dengan meminta pendapat dari peserta workshop ini. Pendapat dari beberapa peserta menunjukkan kelebihan dari kegiatan ini yaitu: (a) kegiatan workshop ini menambah wawasan saya tentang penulisan artikel ilmiah, (b) pembahasan mengenai tata cara menulis artikel ilmiah sudah baik dan mudah dipahami, dan (c) saya menjadi termotivasi dan percaya diri dalam menulis artikel ilmiah. Sedangkan kekurangan dari kegiatan ini yaitu: (a) audio kurang jelas untuk via online, (b) waktu pemaparan materi hendaknya dipersingkat atau dibagi menjadi beberapa bagian, sehingga lebih peserta lebih memahami materi yang disampaikan. Setelah kegiatan workshop ini selesai, maka kegiatan ini ditutup dengan foto bersama (lihat Gambar 4).

Secara umum hasil pengabdian ini berkonstribusi terhadap pemahaman peserta dalam menulis artikel ilmiah. Hasil pengabdian menunjukkan bahwa peserta sudah memahami materi yang disampaikan, yaitu: (a) memahami tahapan menulis artikel ilmiah, (b) memahami penulisan dari masing-masing komponen artikel ilmiah, dan (c) memahami cara mengirim artikel ilmiah ke jurnal terakreditasi sinta. Pemahaman pertama yang didapat oleh peserta atau mahasiswa dalam mengikuti kegiatan ini yaitu pemahaman terhadap tahapan menulis artikel ilmiah. Sebelum mengikuti kegiatan ini, mahasiswa masih kesulitan tentang bagaimana tahapan dalam menulis artikel ilmiah. Tahapan penulisan ilmiah yang disampaikan dalam pengabdian ini terdiri dari: (a) mencari dan memilih jurnal terakreditasi, (b) mendownload beberapa artikel dari jurnal tersebut sebagai contoh, (c) memulai penulisan artikel, (d) melakukan editor, dan (e) menyempurnakan tulisan. Hasil pengabdian ini menunjukkan bahwa kelima tahapan penulisan artikel ini mudah dipahami oleh mahasiswa.

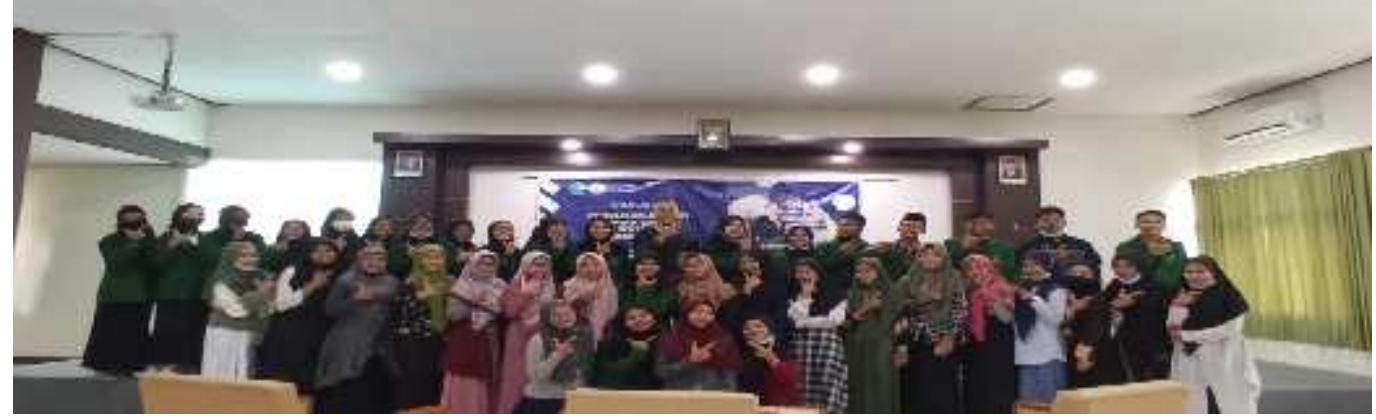

Gambar 4. Foto Bersama Pemateri dengan Peserta Workshop 
Pemahaman kedua yang diperoleh oleh peserta atau mahasiswa adalah memahami penulisan artikel ilmiah. Penulisan artikel ilmiah ini bukanlah pekerjaan yang mudah. Berbagai hasil pengabdian menunjukkan bahwa peserta pengabdian yang terdiri dari guru maupun mahasiswa masih kesulitan dalam membuat artikel ilmiah (Marwoto et al., 2013; Setianingsih et al., 2020; Susantini et al., 2015; Wahyuningtyas \& Ratnawati, 2018). Kesulitan ini dapat dikurangi dengan memberikan pemahaman dalam penulisan artikel ilmiah berdasarkan komponen artikel ilmiah. Hasil penelitian menunjukkan bahwa pemahaman terhadap komponen dari suatu materi dapat menyebabkan keberhasilan dalam belajar (Mustangin \& Setiawan, 2021; Setiawan, 2020c, 2020d, 2020a) dan sebaliknya kurangnya pemahaman terhadap komponen materi dapat menyebabkan kesalahan (Setiawan, 2021c, 2021a; Setiawan \& Mustangin, 2020). Oleh sebab itu, penyampaian materi tentang penulisan karya ilmiah ini dilakukan sesuai komponen artikel ilmiah. Komponen artikel ilmiah terdiri dari: judul, penulis, abstrak, kata kunci, pendahuluan, metode, hasil, pembahasan, kesimpulan, ucapan terima kasih, dan daftar pustaka. Hasil pengabdian ini menunjukkan bahwa pembahasan satu per satu mengenai penulisan komponen artikel tersebut dapat menambah pemahaman mahasiswa atau peserta dalam menulis artikel ilmiah. Oleh sebab itu, penting bagi para pengabdi untuk mengetahui cara menyusun komponen dari suatu artikel dengan benar.

Pemahaman ketiga yang diperoleh oleh peserta atau mahasiswa adalah memahami cara mengirim artikel ke jurnal terakreditasi sinta. Prosedur pengiriman artikel ke suatu jurnal, yaitu: (a) melakukan registrasi sebagai penulis, (b) melakukan pengiriman artikel, (c) menunggu proses pre-review, (d) melakukan revisi dan mengirim artikelnya kembali, (e) menunggu proses review, (f) melakukan revisi dan mengirimkan artikel kembali (jika dimungkinkan pada tahap ini akan terjadi beberapa kali revisi), (g) menyelesaikan administrasi, dan (h) penerbitan artikel. Agar mudah dipahami oleh peserta, pengabdi memberikan contoh pengiriman artikel yang telah disiapkan oleh pengabdi. Melalui contoh konkret ini, mahasiswa dapat lebih memahami tentang cara mengirimkan artikel ilmiah pada jurnal terakreditasi sinta.

Dengan demikian, ketiga pengetahuan yang penting untuk dimiliki oleh seorang mahasiswa dalam menulis artikel ilmiah yaitu: tahapan penulisan, proses penulisan, dan tahapan pengiriman artikel ilmiah. Hal ini dikarenakan agar mahasiswa berhasil dalam menulis artikel ilmiah yang benar. Selain itu, lancar atau tidaknya suatu workshop tidak lepas dari berbagai pihak. Dimana hasil pengabdian menunjukkan bahwa kehadiran pimpinan, motivasi dan keaktifan peserta, serta rasa percaya diri dan penguasaan materi oleh pemateri merupakan faktor-faktor yang mendukung keberhasilan suatu pengabdian baik dalam bentuk pelatihan, seminar, workshop, ataupun lokakarya (Setiawan, 2020b, 2020e; Setiawan \& Syaifuddin, 2020). Dengan demikian penting untuk menjalin kerja sama yang baik antara panitia, peserta, dan pemateri, agar kegiatan pengabdian dapat berjalan dengan lancar dan sukses.

Sebagai kegiatan tindak lanjut dari hasil kegiatan workshop ini adalah melakukan kegiatan pendampingan kepada mahasiswa dalam menyusun artikel ilmiah sampai mahasiswa dapat menulis artikel ilmiah dengan benar dan dapat melakukan publikasi ilmiah di jurnal nasional terakreditasi sinta. Kegiatan pendampingan penulisan artikel ini dapat dilakukan oleh para dosen yang melakukan pembimbingan skripsi. Kegiatan pendampingan ini membutuhkan waktu sekitar 6 bulan. 


\section{Kesimpulan}

Berdasarkan hasil pengabdian ini dapat disimpulkan bahwa kegiatan workshop ini telah berhasil memberikan pemahaman kepada peserta dalam penulisan artikel ilmiah untuk publikasi di jurnal terakreditasi sinta. Hal ini dapat diketahui dari hasil evaluasi kegiatan pengabdian yang menunjukkan bahwa hasil pengisian angket berada pada kategori sangat tinggi yaitu $86,6 \%$, yang berarti bahwa pengabdian ini sangat berhasil.

\section{Saran}

Adapun saran untuk kegiatan pengabdian berikutnya yakni kepada para dosen atau pengabdi agar lebih spesifik, yaitu tentang penulisan artikel hasil penelitian kuantitatif, hasil penelitian kualitatif, dan hasil penelitian pengembangan. Spesifikasi kegiatan pengabdian dapat dilakukan berdasarkan anatomi artikel. Misalnya, hanya membahas mengenai cara menulis pendahuluan yang baik dalam artikel ilmiah. Dengan demikian, kegiatan workshop ini akan menambah wawasan mahasiswa atau peserta dalam menulis artikel ilmiah.

\section{Daftar Pustaka}

Creswell, J. W. (2012). Educational Research Planning, Conducting and Evaluating Quantitative and Qualitative Research (Fourth). Pearson Education, Inc.

Surat Edaran Nomor 152/E/T/2012 Perihal Publikasi Karya Ilmiah, Direktorat Jenderal Pendidikan Tinggi 1 (2012).

Hia, Y. D., Sumarni, \& Armiati. (2016). Pelatihan Metode Pembelajaran Inovatif untuk Meningkatkan Profesionalisme Guru SMA. Jurnal Pelangi, 8(2), 243-249. http://ejournal.stkip-pgri-sumbar.ac.id/index.php/pelangi/article/download/1206/pdf

KBI. (2008). Kamus Bahasa Indonesia. Pusat Bahasa Departemen Pendidikan Nasional.

Marwoto, P., Sopyan, A., Linuwih, S., \& Subali, B. (2013). Peningkatan Kemampuan Menulis Artikel Ilmiah Sains Guru Sekolah Dasar Melalui Kegiatan Pengabdian Masyarakat. Jurnal Abdimas, 17(2), 111-116.

Mustangin, \& Setiawan, Y. E. (2021). Pemahaman Konsep Mahasiswa Semester Satu pada Mata Kuliah Trigonometri. Jurnal Elemen, 7(1), 98-116. https://doi.org/10.29408/jel. v7i1.2773

Setianingsih, T., Qomariyah, S., Ariani, S., \& Suhaili, M. (2020). Pelatihan Penulisan Karya Tulis bagi Guru SMA Hang Tuah 3 Mataram. Jurnal Pengabdian UNDIKMA, 1(1). doi:https://doi.org/10.33394/jpu.v1i1.2549

Setiawan, Y. E. (2020a). Analisis Kemampuan Siswa dalam Pembuktian Kesebangunan Dua Segitiga. Al-Khwarizmi: Jurnal Pendidikan Matematika Dan Ilmu Pengetahuan Alam, 8(1), 23-38. https://doi.org/http://dx.doi.org/10.24256/jpmipa.v8i1.800

Setiawan, Y. E. (2020b). Pelatihan desain peta konsep menggunakan aplikasi cmaptools. Jurnal PKM: Pengabdian Kepada Masyarakat, 03(04), 395-403. https://doi.org/http://dx.doi.org/10.30998/jurnalpkm.v3i4.5567

Setiawan, Y. E. (2020c). Proses Berpikir Siswa dalam Memperbaiki Kesalahan Generalisasi Pola Linier. Mosharafa: Jurnal Pendidikan Matematika, 9(3), 371-382. https://doi.org/https://doi.org/10.31980/mosharafa.v9i3.751

Setiawan, Y. E. (2020d). The Thinking Process of Students Using Trial and Error Strategies in Generalizing Linear Patterns. Numerical: Jurnal Matematika Dan Pendidikan Matematika, 4(1), 1-12. https://doi.org/https://doi.org/10.25217/numerical.v4i1.839

Setiawan, Y. E. (2021a). Analisis Kesalahan Mahasiswa Semester Pertama dalam Menentukan Nilai Fungsi Trigonometri Sudut Istimewa. Supremum Journal of 
Mathematics Education, 5(1), 110-121. https://doi.org/https://doi.org/10.35706/ sjme.v5i1.4531

Setiawan, Y. E. (2021b). Kebutuhan Kegiatan Webinar Tentang Disposisi Berpikir. Ethos: Jurnal Penelitian Dan Pengabdian Kepada Masyarakat, 9(2), 288-295. https://doi.org/https://doi.org/10.29313/ethos.v9i2.7651

Setiawan, Y. E. (2021c). Kesalahan Mahasiswa Semester Pertama dalam Menyelesaikan Masalah Fungsi Trigonometri Sudut Tidak Lancip. Aksioma: Jurnal Program Studi Pendidikan Matematika, $10(2)$,

599-614. https://doi.org/https://doi.org/10.24127/ajpm. v10i2.3458

Setiawan, Y. E. (2020e). Analisis Faktor-Faktor Pendukung Keberhasilan Pelaksanaan Pelatihan Terhadap Guru. Prosiding Konferensi Nasional Pengabdian Kepada Masyarakat: KKN Tematik Untuk Mewujudkan Masyarakat Tangguh Guna Percepatan Pembangunan Di Era Pandemi Covid-19: 7 Desember 2020, 545-557.

Setiawan, Y. E., \& Mustangin. (2020). Validitas Model Pembelajaran IDEA ( Issue, Discussion, Establish, and Apply) untuk Meningkatkan Pemahaman Konsep. Jurnal Penelitian Pendidikan Dan Pengajaran Matematika, 6(1), 53-60. https://doi.org/https://doi.org/10.37058/jp3m.v6i1.1432

Setiawan, Y. E., \& Syaifuddin. (2020). Peningkatan Kompetensi Profesionalitas Guru Melalui Pelatihan Desain Pembelajaran Peta Konsep. Jurnal Pengabdian Kepada Masyarakat, 26(3), 148-153. https://doi.org/http://dx.doi.org/10.24114/jpkm.v26i3. 16377

Suadiyatno, T., Sumarsono, D., Muliani, M., Arrafii, M., \& Bagis, A. (2020). Pelatihan Strategi Penulisan Artikel Ilmiah pada Jurnal Bereputasi Nasional dan Internasional bagi Guru di SMKN 1 Sekotong Kabupaten Lombok Barat. Jurnal Pengabdian UNDIKMA, 1(2), 139-143. doi:https://doi.org/10.33394/jpu.v1i2.2936

Susantini, E., Rahayu, Y. S., Budiono, D., \& Raharjo, R. (2015). Profil Artikel Ilmiah Buatan Guru Pada Pelatihan Penulisan Karya Ilmiah Bagi Guru - Guru Di Smp Lab School Surabaya. Jurnal ABDI, 1(1), 1-7. https://doi.org/10.26740/ja.v1n1.p1-7

Sutrisno, S., \& Zuhri, M. S. (2019). PKM Peningkatan Kompetensi Guru Melalui Pelatihan Penulisan Artikel Ilmiah Penelitian Tindakan Kelas. Journal of Dedicators Community, 3(1), 53-61. https://doi.org/10.34001/jdc.v3i1.793

Utami, S. D., Primawati, S. N., \& Fitriani, H. (2020). Pelatihan Penulisan Artikel Ilmiah bagi Mahasiswa Pendidikan Biologi FPMIPA IKIP Mataram. Jurnal Pengabdian UNDIKMA: Jurnal Hasil Pengabdian \& Pemberdayaan Kepada Masyarakat, 1(1), 22-27.

Wahyuningtyas, N., \& Ratnawati, N. (2018). Pelatihan dan Pendampingan Penulisan Artikel Jurnal Bagi Guru-Guru IPS Kabupaten Malang. Jurnal Praktis Dan Dedikasi Sosial, $1(1), 39-45$. 